\title{
Evaluation of the macroscopic growth degree of experimental endometriosis in rats
}

\author{
Avaliação do grau de crescimento macroscópico da \\ endometriose experimental em ratos
}

\author{
João Nogueira Neto ${ }^{2}$, Orlando Jorge Martins Torres ${ }^{3}$, Tarcísio Mota Coelho ${ }^{4}$, Joel Nicolau Nogueira Nunes Júnior ${ }^{5}$, \\ Guilherme Carneiro Aguiar ${ }^{4}$, Lícia Kércia de Araújo Costa ${ }^{5}$ \\ 1. Health Science Center and Experimental Surgical Laboratory of Universidade Federal do Maranhão, São Luis, Maranhão, Brazil. \\ 2. Postgraduate student at Federal University of Maranhão, São Luís, Maranhão, Brazil. \\ 3. Professor of Surgery- Federal University of Maranhão, São Luís, Maranhão, Brazil.. \\ 4. Assistent Professor - Federal University of Maranhão, São Luís, Maranhão, Brazil. \\ 5. Medical Student - Federal University of Maranhão, São Luís, Maranhão, Brazil.
}

\begin{abstract}
Purpose: To evaluate macroscopically the growth degree of self-transplantation of endometriosis in rats. Methods: Forty female rats, after a 7-day period for adpating and evaluating of the estrous cycle regularity, underwent tail abdominal midline laparotomy with 3-cm cuts. The average third of the left uterine horn was removed, $4 \mathrm{~mm} x 4 \mathrm{~mm}$ patches in liquid environment were made, and self-transplanted in the rat mesenterium with a single stitch, and the endometrial surface of the endometriotic implant facing the lumen of the peritoneal cavity. The rats were programmed to die after three weeks. The abdominal cavity displaying was held and self-transplants were identified and classified. Results: The results achieved were: one case for degree 0 (2,5\%), three cases for degree 1 (7,5\%), eleven cases for degree II (27,5\%) and twenty-five cases for degree III (62,5\%). Conclusion: The experimental endometriosis development, through the self-transplantation technique, showed to be most common in degrees 3 and 2 of development.
\end{abstract}

Key words: Endometriosis. Animal Experimentation.

\section{RESUMO}

Objetivo: Avaliar macroscopicamente o grau de crescimento de autotransplantes de endometriose em ratos. Métodos: Quarenta ratos fêmeas, após período de sete dias para adaptação e avaliação da regularidade do ciclo estral, foram submetidas à laparotomia mediana abdominal caudal com incisões de três cm. Foi retirado o terço médio do corno uterino esquerdo, feito retalhos de quatro mm x quatro mm em meio líquido, sendo em seguida autotransplantado no mesentério da rata com ponto simples, tomando o cuidado de manter a superfície mucosa voltada para luz abdominal. Após o período de três semanas as mortes das ratas foram programadas. Realizou-se a exposição da cavidade abdominal com identificação e classificação dos autotransplantes. Resultados: os resultados encontrados foram: grau 0 obteve um caso (2,5\%), o grau I foi observado em três casos (7,5\%), o grau II com onze casos (27,5\%) e o grau III foi visto em vinte cinco casos (62,5\%). Conclusão:Desenvolve-se a endometriose experimental pela técnica do autotransplante com a maioria dos casos em grau 3 e 2 de desenvolvimento.

Descritores: Endometriose. Experimentação Animal. 


\section{Introduction}

Endometriosis is a clinical and pathologic disturbance, featured by the presence of structural tissue, functionally similar to the endometrial tissue, out of the uterine cavity. The main endometriosis manifestations are pelvic pain and infertility. The treatment is clinical and surgical, and its medicine therapeutics is preferably the one that interferes in the menstruation cycle, inducing pseudopregnancy, pseudomenopause or chronicle anovulation, providing clinical betterments, but they have no healing effects, which justifies the experimental search for new treatments ${ }^{1}$. Experimental researches on endometriosis were stimulated after a study held by Vernon et al. ${ }^{2}$, who created the surgical technique of uterine tissue transplantation in rats in order to develop peritoneal experimental endometriosis. More recently, the use of green fluorescent protein (GFP)cDNA as a marker of the ectopic endometrial tissue in a noninvasive model has been indicated ${ }^{3}$. A study on the endocrine state and the endometrial cells in adherences in a experimental model on rats showed that, for the development of experimental endometriosis, two factors are necessary: the procedures have to be made in a period of largest hormone production of the ovarian cycle, and the material for self-transplantation must have endometrial cells and stromal tissue ${ }^{4}$. Quereda et al. ${ }^{5}$, in a study on the individual and combined effect of triptoreline and gestrinone in experimental endometriosis in rats, presented a macroscopic classification of the self-transplantations, based mainly on the cystic formations of the self-transplantations. That macroscopic classification has become a parameter to evaluate the success of treatments with experimental medicines. In order to achieve the development and the mastering of the technique in experimental endometriosis, for the use of drugs to be tested against experimental endometriosis, we aimed at classifying, under macroscopic aspects, the experimental endometriosis induced through self-transplantations in rats.

\section{Methods}

This was an experimental study, held during the period between June and July of 2006, with samples of 40 Wistar rats (Rattus norvegicus albinus), adults, females, virgins, weighing between 180 and 250 grams, with 60 days of life, subsided for the central office of the Biotery of the Federal University of Maranhão (UFMA). The research was developed in the Experimental Surgical Laboratory of the Hospital of the Federal University of the Maranhão. It had been respected the Brazilian legislation for the use of experimentation animals (Federal Law number 6.638/1979) and norms of the Brazilian College of Animal Experimentation (COBEA), which is an institution associated to The International Council for Laboratory Animal Science. The study was approved by the Committee of Ethics and Animal Experimentation (CEEA-UEMA), protocol 05/2006. The animals had been grouped in number of five in each polypropylene river steamer with a cover of stainless metallic grating, measuring $46 \mathrm{~cm}$ x $31 \mathrm{~cm}$ x $16 \mathrm{~cm}$ with bottom lined with paper that was changed each 48 hours. Then, the animals had been divided in eight groups kept in constant ambient conditions, receiving standard rat chow (PURINA®, São Paulo, Brazil) and water ad libitum during seven days for adaptation. Noise was controlled, and temperature was kept $22^{\circ} \mathrm{C} \pm 2{ }^{\circ} \mathrm{C}$, relative humidity $40 \%$ to $60 \%$, cycles clear/dark of 12/12 hours. Collection and analysis of vaginal cytologic smears had been carried out daily. Only those rats exhibiting four or more consecutive estrous cycles of either 4 or 5 days were used. After 12 fasting, the animals had been weighed with electronic scale (MARTE, model A500, 110-200, Brazilian Industry) and anesthetized with a mixture of $2 \%$ xilazine and $5 \%$ ketamine in the ration in 1:1 rate, in a dose of $0,2 \mathrm{ml}$ for each $100 \mathrm{~g}$ of weight through intramuscular rote using hypodermic needle of 13mm x 4, $5 \mathrm{~mm}$ (Becton Dickinson, Paraná, Brazil), in the posterior edge of the left thigh. The animals had been considered anesthetized because of the absence of interdigital corneanos reflexes; after that, they had been immobilized in a wooden plate of $20 \mathrm{~cm} \times 30 \mathrm{~cm}$, and the abdominal surface was shaved and rinsed with Polivinilpirrolidona-iodo (Povidine Tópico®, São Paulo - SP).

A $3 \mathrm{~cm}$ midline incision was carried out with 15 Fr scapel assaulting skin, aponeurotic-muscle plan and peritoneal, followed by identification of the peritoneal cavity organs and exposition of the uterus, annexes and mesentery. The left uterine horn was transected $5 \mathrm{~mm}$ cranial to the junction between the two cornua. Concomitantly, the extracted part of the uterus was sliced in longitudinal cuts followed of transversal cuts forming remnants with measures of $4 \mathrm{~mm} x$ $4 \mathrm{~mm}$, in liquid area with Ringer Lactate, where nylon point of 6-0 in the serosal surface of the remnant was transferred and kept wire repaired (Figure 1).

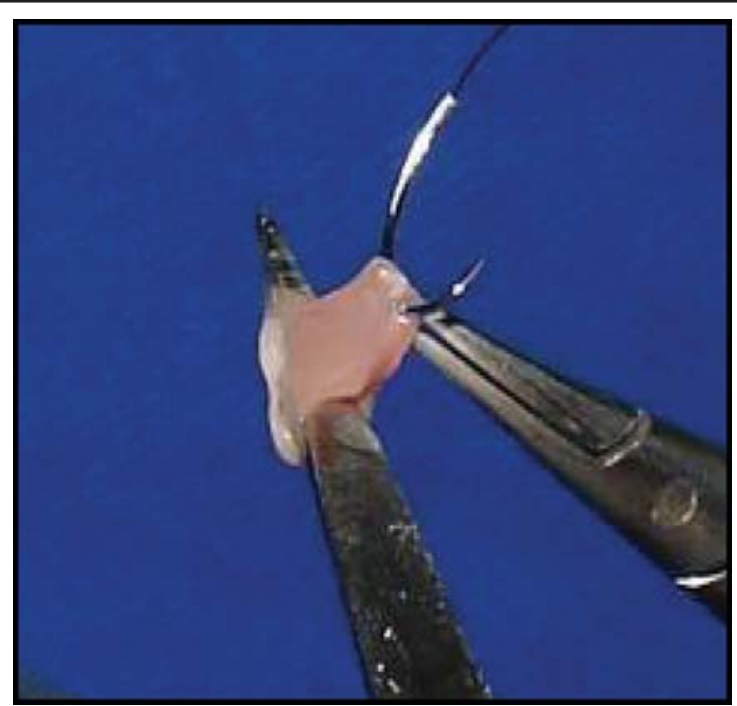

FIGURE 1 - Photomicrography of the left uterine horn patch, during 6-0 nylon stitch passing through the patch surface. 
The remnant suffered auto transplantation in the mesentery, next to the vase that irrigates the cecum remaining the serosal surface in contact with the mesentery and the endometrial surface directed toward the light of the peritoneal cavity (Figure 2). The setting was made with a simple point of the remnant repaired.

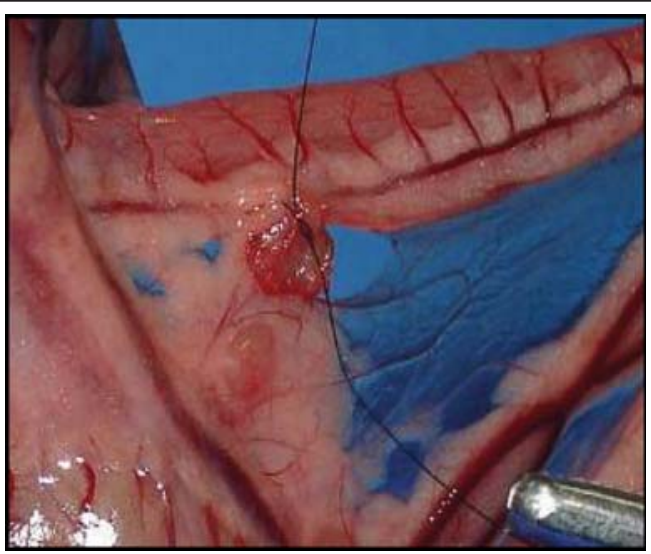

FIGURE 2 - Photomicrography showing self-transplantation in mesenterium attached with single stitch with 6-0 nylon, the endometrial surface of the endometriotic implant facing the lumen of the peritoneal cavity.

The synthesis of the abdominal wall was carried through into two plans of continuous suture assaulting the aponeurotic muscle plan and the skin with 5-0 nylon. The animals had remained in the laboratory for a period of 21 days. After that period the animals had been weighed and placed in ether vaporizer until the death, characterized for muster respiratory and complete absence of reflexes. Confirmed the death of the animals, they had been settled in wooden plate in dorsal decubitus with adhesive ribbon. Then, all the abdominal ventral area was shaved, followed by two transversal incisions: above, bordering the costal rim; and below, bordering the pelvic bones, and there was a third lateral left longitudinal incision, joining the transversal incisions, displaying completely the peritoneal cavity. The inventory of the peritoneal cavity with identification and measure of the focus of auto transplantation. It was used the system of classification of the growth of the implants in accordance to Quereda et $\mathrm{al}^{4}$ was used with modification, classified of the following way: degree 0 - implantation disappears or absence of the cystic form; degree I - implantation forms a vesicle with smaller diameter than two millimeters or solid form; degree II - implantation is cystic with fluid and its diameter is between $2 \mathrm{~mm}$ and smaller than $4,5 \mathrm{~mm}$; and degree III - vesicle with bigger diameter than $4,5 \mathrm{~mm}$.

\section{Results}

The macroscopic evaluation according to Quereda et $\mathrm{al}^{5}$ showed that after the focus are identified or not, either the bladder development is or not identified, followed by diameter measurement, we observed one (2,5\%) case in group $0 ; 3(7,5 \%)$ cases in group I; 11 (27,5\%) cases in group II; and $25(62,5 \%)$ cases in group III (Figures 3 and 4). Curiously, two rats developed two focus each, although only one patch was selftransplanted, one of them with degree II (Figure 5) and the other one, degree III.

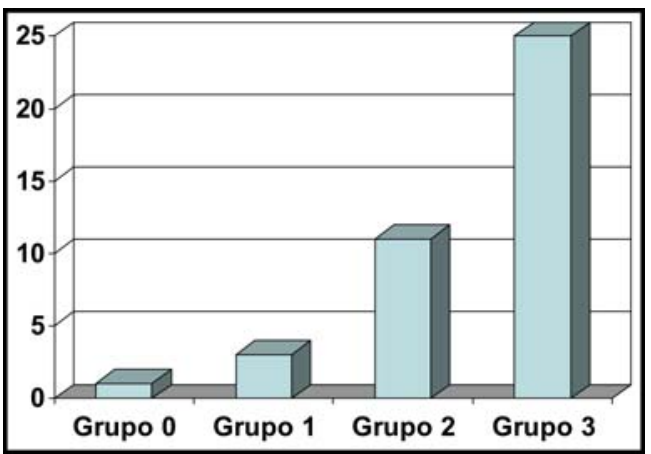

FIGURE 3 - Number of cases in each group of the implantation classification system for growth degree according to Quereda et $\mathrm{al}^{5}$, showing a greater number in the most developed groups (II and III).

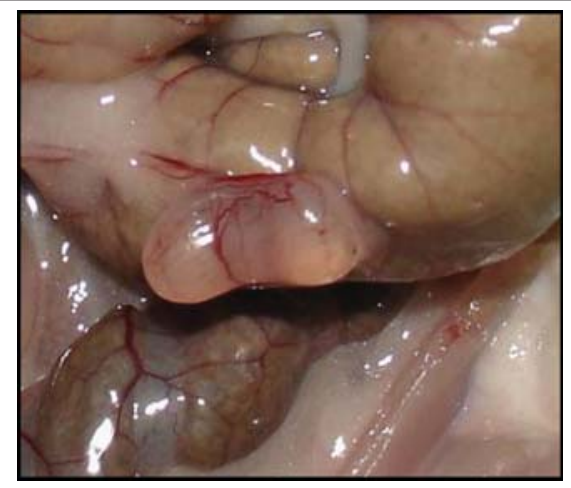

FIGURE 4 - Photomicrography showing self-transplantation mostly found in our study, degree III in the implantation classification system for growth degree according to Quereda et $\mathrm{al}^{5}$, with diameter above $4,5 \mathrm{~mm}$.

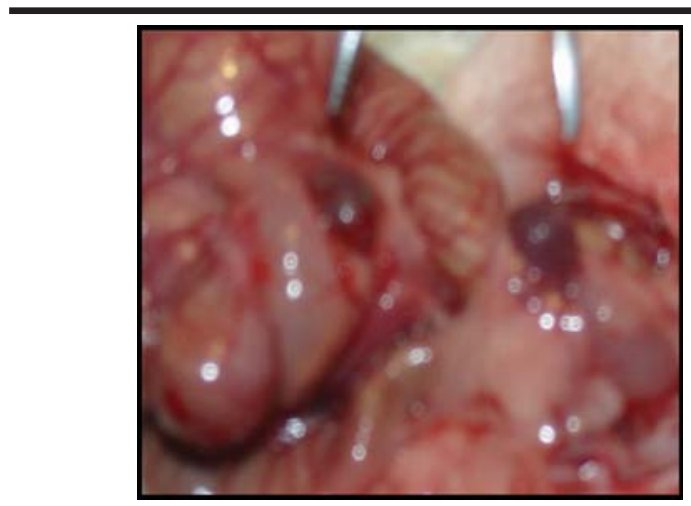

FIGURE 5 - Photomicrography of self-transplantation degree II for growth degree according to Quereda et al5, showing the occurrence of two focus from one single patch self-transplantation.

\section{Discussion}

Endometriosis is a disease for which the ideal therapy is still to come. The mostly used drugs currently are medroxiprogesterone acetate, danazol, oral contraceptives 
and GnRH analogues. They bring good results in pain events, but they interfere in fertility, and the treatment cease is followed by endometriosis recurrency ${ }^{8}$. Several drugs have been researched in experimental studies as endometriosis optional therapeutics. The alternatives for estrogen suppression are aromatase and selective estrogen receptors modulators (SERM) inhibitors. Others are immunomodulators ${ }^{9}$, anti-inflammatory agents ${ }^{10}$, BCG vaccin $^{11}$ and statins ${ }^{12}$. Quereda et $\mathrm{al}^{5}$, in a study on triptoreline and gestrinone in experimental endometriosis, for a better comparison of the macroscopic effects of those drugs, the self-transplantations were sorted in groups according to the maximum diameter size, presenting also a stage of experimental endometriosis, taking into account the total diameters of a same rat's focuses, since three patches were self-transplanted in each animal. In our study, we did not perform the stage due to only one patch was self-transplanted, what limited the evaluation of the selftransplantation. Vernon and Wilson's ${ }^{2}$ self-transplantation of experimental endometriosis allowed the use of several drugs against endometriosis. An outstanding example is the study by Kudon et al. ${ }^{13}$, Who analyzed the effect of aromatase inhibitor YM511 in experimental endometriosis in rats and observed, in the control group, an increase of the average volume from $33,00 \mathrm{~mm}^{3}$ to $41,00 \mathrm{~mm}$. This author's experimental groups used YM511 at 0,04; 0,2 and 1 $\mathrm{mg} / \mathrm{Kg}$ and showed a significant volume reduction of the self-transplants when compared with the control group that underwent ooferoctomy in the same study. In this study, the comparison among the groups was made through the volume calculus. The development of experimental endometriosis in our study was satisfactory, in which the lowest development degree (degree 0 ) was present in only one of the forty cases, and the most advanced (degree 3) was present in 25 cases (62,5\%). Developing endometriosis is a great stimulus to develop researches. The use of drugs against endometriosis and the morphologic classification provides us with more reliable samples for comparisons before and after the use of experimental drugs leading us to more reliable results.

\section{Conclusion}

The experimental endometriosis development, through the self-transplantation technique, showed to be most common in degrees 3 and 2 of development.

\section{References}

1. Oliver DL, Pritts AE. Treatment of endometriosis. N Engl J Med. 2001;345(4): 266-75.

2. Vernon MW, Wilson E. A. Studies on the surgical induction of endometriosis in the rat. Fertil Steril. 1985;44(5): 684-93.

3. Fortin M, Lépine M, Pagé M, Osteen K, Massie B, Hugo PE, Steff A. An improved mouse model for endometriosis allows noninvasive assessment of lesion implantation and development. Fertil Steril. 2003;80(suppl. 2): 248-32.

4. Beliard NA, Goffin F, Frankenne FE, Foidart JM. Role of endocrine status and cell type in adhesion of human endometrial cells to the peritoneum in nude mice. Fertil Steril. 2002;78(5):973-8.

5. Quereda F, Barroso J, Acien P. Individual and combined effects of triptoreline and gestrinone on experimental endometriosis in rat. Eur J Obstet Gynecol Reprod Biol. 1996;67: 35-40.

6. Marcondes FK, Bianchi FJE, Tanno AP. Determination of the estrous cycle phases of rats: some helpful considerations. Braz J Biol. 2002;62 (4A): 609-14.

7. Braz F, Rahal SC, Rocha NS, Taga E, Biasi F. Emprego de matriz óssea orgânica bovina e hidroxiapatita no reparo de defeito induzido em crânio de ratas. Act Cir Bras. 2003;18(1):15-19.

8. Dogan E, Saygili U, Posaci C, Tuna B.; Regression of endometrial explants in rats treated with the cyclooxygenase-2 inhibitor rofecoxib. Fertil Steril. 2004;82(3):1115-20.

9. Keenan JA, William-Boyce PK, Massey PJ, Chen TT, Caudle MR, Bukovsky A. Regression of endometrial explants in a rat model of endometriosis treated with the immune modulators loxoribine and levamisole. Fertil Steril. 1999;72(1): 135-41.

10. Vignali M, Infantino M, Matrone R, Chiodo I, Somigliana E, Busacca M, Vigano P. Endometriosis: novel etiopathogenetic concepts and clinical perpectives. Fertil Esteril. 2002; 78(4): 665-78.

11. Gul A, Yasar T, Ugras S. BCG vaccination to prevent implantation of endometriosis: an experimental study in rats. Eur J Obstet Gynecol Reprod Biol. 2001; 98:209-12.

12. Estefandiari N, Ai J, Khazaei M, Javed M, Gotlieb L, Casper RF. Effect of a statin on an in vitro model of endometriosis. Fertil Steril. 2005;84(suppl.1): S123.

13. Kudon M, Susuki Y, Ideyama Y, Nanya T, Mori M, Shikama H. Inhibitory effects of a novel aromatase inhibitor, YM511, on growth of endometrial explants and insulin-like growth factor -I gene expression in rats with experimental endometriosis. J Steroid Biochem Molec Biol. 1997; 63(1-3): 75-80.

\section{Correspondence:}

João Nogueira Neto

Street Mirage of the sun, 19/1001 - Renaissance II

65075-760 São Luis - MA

Fax: (098) 32315010

j.nogueira.n@uol.com.br.
Conflict of interest: none; Source of Financing: CNPq 